\title{
Characteristics of heavy metal accumulation in five wild plants in Huize Lead-Zinc mining area
}

\author{
Fengli Mou ${ }^{1}$, Jingmin Yang ${ }^{1}$, Biwen $\mathrm{Li}^{1}$, Jianjun $\mathrm{Chen}^{1}$ and Jixiu Wang ${ }^{1 *}$ \\ ${ }^{1}$ College of Resources and Environment, Yunnan Agricultural University, Kunming, 650201, China
}

\begin{abstract}
In order to screen out the plants used to repair heavy metal pollution in the soil, five plants and surface soil were collected in the Huize lead-zinc mine area, centered on the hyperaccumulator plant Arabis alpina L. var. parviflora Franch, measured the heavy metal content of in shoot and root of plant and surface soil, and analyzed the characteristics of heavy metal accumulation in plants. The results showed that the soil Cd pollution in the Huize lead-zinc mining area was the most serious; among the five plants, the $\mathrm{Cd}$ bioconcentration factor(BCF) and translocation factor(TF) of A. alpina were more than 1 , and the $\mathrm{TF}$ of $\mathrm{Pb}$ was more than 1; the $\mathrm{TF}$ of Anaphalis margaritacea, Cyananthus inflatus and Arenaria orbiculata to $\mathrm{Cu}$ and $\mathrm{Zn}$ were more than 1 , the $\mathrm{TF}$ of Juncus effusus to $\mathrm{Cd}$ and $\mathrm{Zn}$ were more than 1 . These five plants had good tolerance to heavy metals and were of great significance to the remediation and restoration of heavy metal contaminated soil in lead-zinc mining areas.
\end{abstract}

\section{Introduction}

Lead-zinc mine is an important strategic mineral resource in China [1]. Long-term mining and smelting activities of mineral resources have produced a large number of slag piles and abandoned land, resulted in serious heavy metal pollution in the mining area [2]. Heavy metal pollution of soil in mining areas will lead to soil degradation in farmland and crop yield reduction, thereby threatening the quality and safety of soil in mining areas [3]. Yunnan is rich in mineral resources, with lead-zinc deposits ranking first in the country and second in Asia [4]. The Huize lead-zinc mine in Yunnan is one of the representatives of large-scale lead-zinc deposits in my country. There were old slag piles and waste land generated during mining and smelting in the mining area, which made the surrounding farmlands seriously polluted by heavy metals [5]. Heavy metals enter the human body through soil and crops, and accumulate in the human body, seriously endangering human health.

There are many ways to deal with heavy metal pollution in the soil, among which the greenest and most effective is phytoremediation. This article discussesd Arabis alpina L. var. parviflora Franch(A. alpina), Anaphalis margaritacea(A. margaritacea), Cyananthus inflatus( $C$. inflatus), Arenaria orbiculata(A. orbiculata) and Juncus effusus( $J$. effusus) plants and their rhizosphere surface soil in the Huize lead-zinc mining area were sampled and investigated, and their heavy metal enrichment characteristics were studied and analyzed to provide a theoretical basis for remediation of heavy metal soil pollution in the mining area.

\section{Materials and methods}

\subsection{Overview of the study area}

The Huize lead-zinc mining area is located in the northeastern part of Yunnan, in Huize County, Qujing City, Yunnan Province. The terrain is high in the southwest and low in the northeast. It is mainly mountainous, with an average elevation of $2183 \mathrm{~m}$. It has a subtropical monsoon climate. The annual average temperature is $12.6{ }^{\circ} \mathrm{C}$. The sampling points were Chihong site(CHS), Xiaomaping site(XMP) and Sanduoduo site(SDD)(Figure 1).

\subsection{Sample collection and processing}

The area where the A. alpina southern mustard grows in the mining area was selected, and five plants and surface soil were collected in the area, such as A. alpina, A. margaritacea, C. inflatus, A. orbiculata and J. effusus, which grew naturally and distributed more frequently. Sealsd all samples with polyethylene plastic bags and took them back to the laboratory.

Firstly, the plant samples were rinsed with tap water to clean the soil attached to the surface of the plants, and then the plants were rinsed with deionized water three times, and the plants were divided into shoot and root. Secondly, place the plants in an oven at $105{ }^{\circ} \mathrm{C}$ for 30 min, and dry them at $75^{\circ} \mathrm{C}$ to a constant weight. Finally, they were crushed with a stainless steel grinder. The soil sample is naturally air-dried and passed through a 0.149 mm nylon sieve. 


\subsection{Measurement method}

Concentrated $\mathrm{HNO}_{3}-\mathrm{HClO}_{4}$ and concentrated $\mathrm{HNO}_{3}-\mathrm{H}_{2} \mathrm{O}_{2}$ digestion methods were used to determine the content of $\mathrm{Pb}, \mathrm{Cd}, \mathrm{Cu}$ and $\mathrm{Zn}$ in soil and plants, and then measured with flame atomic absorption spectrophotometer.

\subsection{Data processing and statistical analyses}

Bioconcentration factor $(\mathrm{BCF})=$ heavy metal content in shoot of plant $\left(\mathrm{mg} \mathrm{kg}^{-1}\right) /$ heavy metal content in soil ( $\mathrm{mg}$ $\mathrm{kg}^{-1}$ )

Translocation factor $(\mathrm{TF})=$ heavy metal content in shoot of plant $\left(\mathrm{mg} \mathrm{kg}^{-1}\right) /$ heavy metal content in root of plant ( $\left.\mathrm{mg} \mathrm{kg}^{-1}\right)$

The data were collected and analyzed by Microsoft Excel. One-way analysis of variance (one-way ANOVA) and significance test $(P=0.05)$ were done by IBM SPSS Statistics 22.

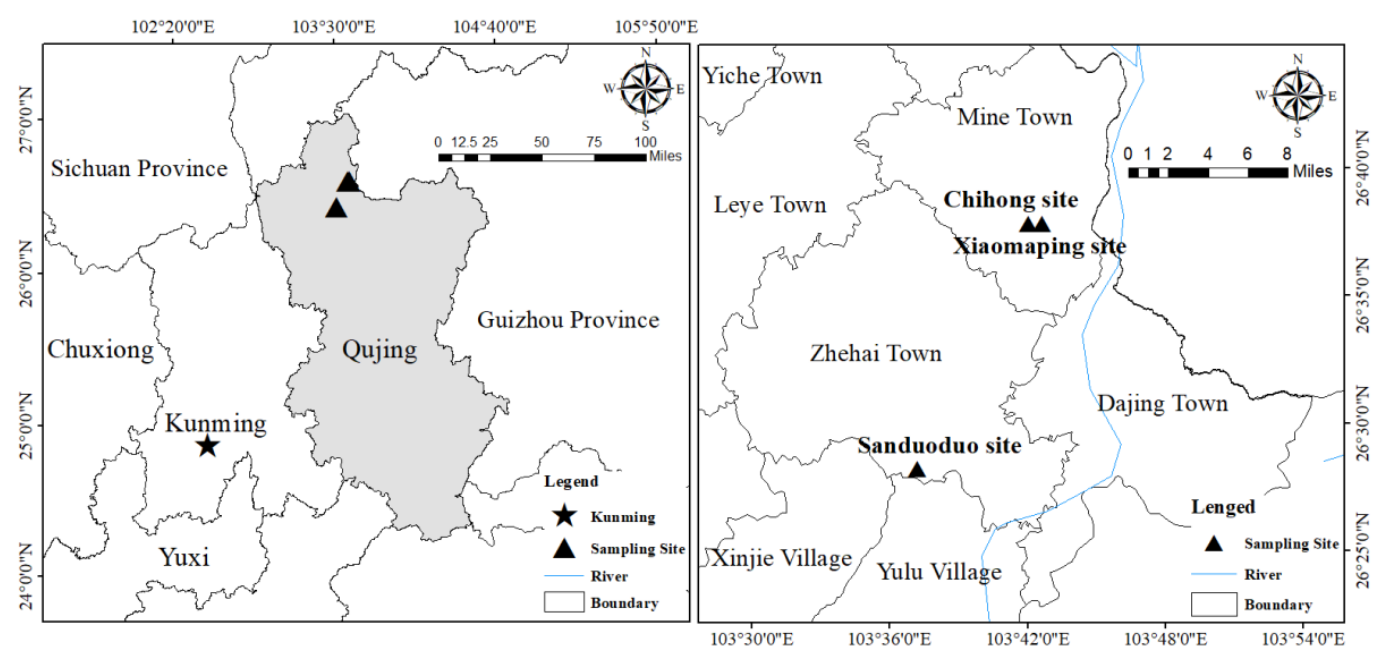

Figure 1. Sampling point location

\section{Results}

\subsection{Soil heavy metal content in mining area}

Compared with the national soil environmental quality standard, the average content of $\mathrm{Pb}, \mathrm{Cd}, \mathrm{Cu}$ and $\mathrm{Zn}$ in the soil was 15.9 times, 38.4 times, 2.7 times and 35.4 times of the standard. Compared with the soil environmental background value in Yunnan Province, the average content of $\mathrm{Pb}, \mathrm{Cd}, \mathrm{Cu}$ and $\mathrm{Zn}$ in the soil was 157.1 times,
262.1 times, 2.9 times and 78.9 times of the standard (Table 1). It can be seen that all four types of heavy metals pollute the soil in the mining area, of which $\mathrm{Cd}$ pollution is the most serious.

\subsection{Characteristics of heavy metal content in plants in mining area}

The contents of $\mathrm{Pb}, \mathrm{Cd}, \mathrm{Cu}$ and $\mathrm{Zn}$ in the five planted objects in the mining area were quite different (Table 2).

Table1. Statistics of heavy metal content in plant root soil in mining area (Unit: $\mathrm{mg} \mathrm{kg}^{-1}$ )

\begin{tabular}{|c|c|c|c|c|}
\hline Site & $\mathrm{Pb}$ & $\mathrm{Cd}$ & $\mathrm{Cu}$ & $\mathrm{Zn}$ \\
\hline CHS & $6654.57 \pm 1071.08 \mathrm{a}$ & $47.57 \pm 23.20 \mathrm{~b}$ & $74.10 \pm 17.63 b$ & $6193.91 \pm 1185.78 b$ \\
\hline XMP & $5593.67 \pm 1897.81 \mathrm{a}$ & $55.98 \pm 28.69 \mathrm{ab}$ & $197.25 \pm 40.17 \mathrm{a}$ & $7002.20 \pm 1019.88 b$ \\
\hline SDD & $7777.80 \pm 1038.48 \mathrm{a}$ & $97.03 \pm 22.81 \mathrm{a}$ & $149.15 \pm 40.97 \mathrm{a}$ & $10281.25 \pm 1661.04 \mathrm{a}$ \\
\hline Average value & 6675.34 & 66.86 & 140.16 & 7825.78 \\
\hline $\begin{array}{l}\text { National soil environmental quality } \\
\text { standard [6] }\end{array}$ & 400.00 & 1.50 & 50.00 & 200.00 \\
\hline $\begin{array}{l}\text { Yunnan Province soil environmental } \\
\text { background value [7] }\end{array}$ & 40.60 & 0.22 & 46.30 & 89.70 \\
\hline
\end{tabular}

Note: Different lowercase letters in the same column indicate a significant difference $(P<0.05)$, the same below.

The content range of each heavy metal in the shoot of the plant was: $\mathrm{Pb} 151.88 \sim 648.34 \mathrm{mg} \mathrm{kg}^{-1}$; $\mathrm{Cd} 5.78 \sim 39.25$ $\mathrm{mg} \mathrm{kg}{ }^{-1}$; $\mathrm{Cu} 15.98 \sim 40.23 \mathrm{mg} \mathrm{kg}^{-1}$; Zn 1149.27 1840.13 $\mathrm{mg} \mathrm{kg}^{-1}$, and the content range of each heavy metal in the root of the plant was: $\mathrm{Pb} 164.73 \sim 1382.81 \mathrm{mg} \mathrm{kg}^{-1} ; \mathrm{Cd}$ 7.99 50.21 mg kg-1; Cu 10.63 334.93 mg kg-1; Zn $1040.63 \sim 1740.86 \mathrm{mg} \mathrm{kg}^{-1}$. The absorption capacity of $A$. alpina to $\mathrm{Pb}, \mathrm{Cd}, \mathrm{Cu}$ and $\mathrm{Zn}$ was greater than that of the 
other four plants.

\subsection{Characteristics of plants' accumulation of heavy metals in mining areas}

The $\mathrm{BCF}$ of $\mathrm{Pb}, \mathrm{Cu}$ and $\mathrm{Zn}$ in five plants were all $<1$, and the BCF of $\mathrm{Cd}$ in A. alpina was $>1$. Except for the $A$. alpina, the $\mathrm{Pb} \mathrm{TF}$ of the other four plants were all $<1$; except for A. alpina and J. effusus, the Cd TF of the other three plants were all $<1$; except for the $J$. effusus, the $\mathrm{Cu}$ $\mathrm{TF}$ of the other four plants were all $>1$; the $\mathrm{Zn} \mathrm{TF}$ of the five plants were all $>1$ (Table 3 ).

Table 2. Heavy metal content in plants in mining area (Unit: mg kg-1)

\begin{tabular}{|c|c|c|c|c|c|c|c|c|c|}
\hline \multirow[t]{2}{*}{ Site } & \multirow[t]{2}{*}{ Plant } & \multicolumn{2}{|c|}{$\mathrm{Pb}$ content } & \multicolumn{2}{|c|}{ Cd content } & \multicolumn{2}{|c|}{$\mathrm{Cu}$ content } & \multicolumn{2}{|c|}{ Zn content } \\
\hline & & Shoot & Root & Shoot & Root & Shoot & Root & Shoot & Root \\
\hline \multirow[t]{4}{*}{ CHS } & A. alpina & $\begin{array}{c}648.34 \pm 7 \\
6.00 \mathrm{a}\end{array}$ & $\begin{array}{l}1502.01 \mathrm{a} \\
44.64 \mathrm{a}\end{array}$ & $\begin{array}{c}39.25 \pm 2 \\
.32 \mathrm{a}\end{array}$ & $.63 \mathrm{a}$ & $\begin{array}{l}1 J .90 \pm 2 . \\
42 \mathrm{c}\end{array}$ & $.98 \mathrm{c}$ & $\begin{array}{c}1765.67 \pm 6 \\
3.76 \mathrm{a}\end{array}$ & $\begin{array}{c}463.30 \pm 1 \\
07.23 \mathrm{~b}\end{array}$ \\
\hline & A. margaritacea & $\begin{array}{c}472.70 \pm 8 \\
6.04 \mathrm{~b}\end{array}$ & $\begin{array}{c}1186.20 \pm 2 \\
04.17 \mathrm{a}\end{array}$ & $\begin{array}{c}7.11 \pm 3 \\
33 \mathrm{c}\end{array}$ & $\begin{array}{c}12.09 \pm 3 \\
.03 \mathrm{bc}\end{array}$ & $\begin{array}{c}27.50 \pm 5 \\
58 \mathrm{ab}\end{array}$ & $\begin{array}{c}24.58 \pm 5 \\
.69 \mathrm{ab}\end{array}$ & $\begin{array}{c}1149.27 \pm 1 \\
69.12 \mathrm{c}\end{array}$ & $\begin{array}{c}1094.87 \pm 1 \\
53.63 \mathrm{c}\end{array}$ \\
\hline & C. inflatus & $\begin{array}{c}210.82 \pm 1 \\
26.67 \mathrm{c}\end{array}$ & $\begin{array}{c}1130.41 \pm 2 \\
64.94 \mathrm{a}\end{array}$ & $\begin{array}{c}15.60 \pm 9 \\
.00 \mathrm{c}\end{array}$ & $\begin{array}{c}20.44 \pm 6 \\
.00 \mathrm{~b}\end{array}$ & $\begin{array}{c}18.12 \pm 4 \\
96 \mathrm{bc}\end{array}$ & & $\begin{array}{c}1228.77 \pm 1 \\
84.31 \mathrm{bc}\end{array}$ & $\begin{array}{c}1080.56 \pm 1 \\
21.79 \mathrm{c}\end{array}$ \\
\hline & A. orbiculata & $\begin{array}{c}235.55 \pm 9 \\
4.11 \mathrm{c}\end{array}$ & $\begin{array}{c}535.05 \pm 18 \\
8.62 \mathrm{~b}\end{array}$ & $\begin{array}{c}12.03 \pm 4 \\
.21 \mathrm{c}\end{array}$ & $\begin{array}{c}17.10 \pm 5 \\
.28 \mathrm{bc}\end{array}$ & $\begin{array}{c}17.95 \pm 9 \\
51 \mathrm{abc}\end{array}$ & $\begin{array}{c}20.41 \pm 2 \\
.24 \mathrm{~b}\end{array}$ & $\begin{array}{c}1375.60 \pm 1 \\
27.08 b c\end{array}$ & $\begin{array}{c}1281.94 \pm 1 \\
30.34 \mathrm{bc}\end{array}$ \\
\hline \multirow[t]{3}{*}{ XMP } & A. alpina & $\begin{array}{c}314.76 \pm 8 \\
4.81 b c\end{array}$ & $\begin{array}{c}287.91 \pm 12 \\
6.78 \mathrm{bc}\end{array}$ & $\begin{array}{c}27.80 \pm 7 \\
.86 \mathrm{bc}\end{array}$ & $\begin{array}{c}37.02 \pm 1 \\
0.72 \mathrm{ab}\end{array}$ & $\begin{array}{c}16.52 \pm 6 \\
38 \mathrm{bc}\end{array}$ & $\begin{array}{c}12.59 \pm 4 \\
.88 \mathrm{c}\end{array}$ & $\begin{array}{c}1501.42 \pm 1 \\
64.92 \mathrm{~b}\end{array}$ & $\begin{array}{c}1478.83 \pm 1 \\
88.70 \mathrm{abc}\end{array}$ \\
\hline & A. margaritacea & $\begin{array}{c}265.74 \pm 1 \\
32.17 \mathrm{bc}\end{array}$ & $\begin{array}{c}356.59 \pm 16 \\
5.02 \mathrm{bc}\end{array}$ & $\begin{array}{c}5.78 \pm 4 \\
97 \mathrm{c}\end{array}$ & $\begin{array}{c}8.97 \pm 4 \\
92 \mathrm{bc}\end{array}$ & $\begin{array}{c}40.23 \pm 1 \\
5.00 \mathrm{a}\end{array}$ & $\begin{array}{c}34.93 \pm 6 \\
.47 \mathrm{a}\end{array}$ & $\begin{array}{c}1221.97 \pm 1 \\
12.71 \mathrm{c}\end{array}$ & $\begin{array}{c}1040.63 \pm 1 \\
95.25 \mathrm{c}\end{array}$ \\
\hline & C. inflatus & $\begin{array}{c}143.28 \pm 6 \\
0.19 \mathrm{c}\end{array}$ & $\begin{array}{c}254.10 \pm 92 . \\
52 \mathrm{bc}\end{array}$ & $\begin{array}{c}13.45 \pm 4 \\
.48 \mathrm{c}\end{array}$ & $\begin{array}{c}20.54 \pm 4 \\
.57 \mathrm{~b}\end{array}$ & $\begin{array}{c}24.54 \pm 2 \\
69 \mathrm{ab}\end{array}$ & $\begin{array}{c}25.51 \pm 5 \\
.17 \mathrm{ab}\end{array}$ & $\begin{array}{c}1162.07 \pm 1 \\
62.52 \mathrm{c}\end{array}$ & $\begin{array}{c}1040.47 \pm 1 \\
80.08 \mathrm{c}\end{array}$ \\
\hline \multirow[t]{3}{*}{ SDD } & A. alpina & $\begin{array}{c}202.69 \pm 5 \\
0.49 \mathrm{c}\end{array}$ & $\begin{array}{c}232.28 \pm 78 \\
51 \mathrm{c}\end{array}$ & $\begin{array}{c}32.03 \pm 4 \\
.28 b\end{array}$ & $\begin{array}{c}24.98 \pm 1 \\
1.74 b\end{array}$ & $\begin{array}{c}28.79 \pm 2 \\
36 \mathrm{ab}\end{array}$ & $\begin{array}{c}16.08 \pm 1 \\
.09 \mathrm{c}\end{array}$ & $\begin{array}{c}1840.13 \pm 5 \\
3.07 \mathrm{a}\end{array}$ & $\begin{array}{c}1740.86 \pm 1 \\
15.11 \mathrm{a}\end{array}$ \\
\hline & A. orbiculata & $\begin{array}{c}151.88 \pm 5 \\
8.12 \mathrm{c}\end{array}$ & $\begin{array}{c}164.73 \pm 81 \\
91 \mathrm{c}\end{array}$ & $\begin{array}{c}12.37 \pm 1 \\
.64 \mathrm{c}\end{array}$ & $\begin{array}{c}18.67 \pm 0 \\
.92 b\end{array}$ & $\begin{array}{l}21.28 \pm 1 \\
1.48 \mathrm{abc}\end{array}$ & $\begin{array}{c}15.40 \pm 4 \\
.22 \mathrm{bc}\end{array}$ & $\begin{array}{c}1590.13 \pm 1 \\
43.57 \mathrm{ab}\end{array}$ & $\begin{array}{c}1636.00 \pm 1 \\
31.33 \mathrm{ab}\end{array}$ \\
\hline & J. effusus & $\begin{array}{c}201.03 \pm 1 \\
06.95 \mathrm{c}\end{array}$ & $\begin{array}{c}315.84 \pm 16 \\
7.69 \mathrm{bc}\end{array}$ & $\begin{array}{c}9.07 \pm 2 . \\
01 \mathrm{c}\end{array}$ & $\begin{array}{c}7.99 \pm 4 \\
43 \mathrm{c}\end{array}$ & $\begin{array}{c}26.98 \pm 8 \\
69 \mathrm{abc}\end{array}$ & $\begin{array}{c}28.11 \pm 2 \\
.28 \mathrm{a}\end{array}$ & $\begin{array}{c}1361.49 \pm 1 \\
85.49 \mathrm{bc}\end{array}$ & $\begin{array}{c}1193.41 \pm 1 \\
26.78 \mathrm{c}\end{array}$ \\
\hline
\end{tabular}

Table 3. Heavy metal BCF and TF of the plants in mining area

\begin{tabular}{cccccccccc}
\hline Site & Plant & \multicolumn{2}{c}{$\mathrm{Pb}$} & \multicolumn{2}{c}{$\mathrm{Cd}$} & \multicolumn{2}{c}{$\mathrm{Cu}$} & \multicolumn{2}{c}{$\mathrm{Zn}$} \\
& & $\mathrm{BCF}$ & $\mathrm{TF}$ & $\mathrm{BCF}$ & $\mathrm{TF}$ & $\mathrm{BCF}$ & $\mathrm{TF}$ & $\mathrm{BC}$ & $\mathrm{TF}$ \\
& & & & & & & & $\mathrm{F}$ & \\
\hline CHS & A. alpina & 0.26 & 0.55 & 1.91 & 0.79 & 0.32 & 1.91 & 0.48 & 1.21 \\
& A. margaritacea & 0.32 & 0.69 & 0.46 & 0.65 & 0.76 & 1.17 & 0.66 & 1.13 \\
& C. inflatus & 0.27 & 0.21 & 0.82 & 0.88 & 0.58 & 1.16 & 0.76 & 1.19 \\
& A. orbiculata & 0.16 & 0.48 & 0.73 & 0.80 & 0.53 & 0.89 & 0.92 & 1.13 \\
XMP & A. alpina & 0.08 & 1.23 & 0.70 & 0.83 & 0.20 & 1.67 & 0.40 & 1.02 \\
& A. margaritacea & 0.12 & 0.69 & 0.44 & 0.55 & 0.41 & 1.28 & 0.39 & 1.23 \\
\multirow{3}{*}{ SDD } & C. inflatus & 0.08 & 0.60 & 0.77 & 0.64 & 0.26 & 1.00 & 0.38 & 1.18 \\
& A. alpina & 0.06 & 0.89 & 0.51 & 1.32 & 0.30 & 1.79 & 0.33 & 1.03 \\
& A. orbiculata & 0.04 & 0.93 & 0.31 & 0.66 & 0.24 & 1.34 & 0.30 & 0.97 \\
& J. effusus & 0.08 & 0.67 & 0.15 & 1.37 & 0.35 & 0.94 & 0.25 & 1.00 \\
\hline
\end{tabular}


It can be seen that the TF of four heavy metals in $A$. alpina are all $>1$, and it had a strong transport capacity.

\section{Discussion}

In order to adapt to the severe living environment in places with severe heavy metal pollution, plants have evolved certain defense mechanisms through long-term natural selection [8]. Studies have shown that dominant plants growing in mining areas have a certain tolerance to heavy metals, but each plant has different adaptability and resistance to different heavy metals. Wan et al. investigated the plants in four mines in Hunan and found that Viola principis had a strong ability to accumulate $\mathrm{Cd}$, $\mathrm{Pb}$ and $\mathrm{As}$ [9]. Li Siliang et al. studied the heavy metal accumulation characteristics of dominant plants naturally grown in four lead-zinc mines in Zhejiang Province and found that Elsholtzia argyi and Sedum plumbizincicola had the ability to accumulate $\mathrm{Cd}[10]$.

In this study, $\mathrm{Pb}, \mathrm{Cd}, \mathrm{Cu}$ and $\mathrm{Zn}$ in the surface soil collected from the Huize lead-zinc mining area all exceeded the standard. Among them, Cd was the most polluted, which caused heavy metal pollution in the surrounding farmland soil and was not conducive to crop growth. Among the 5 plants selected in the mining area, the absorption capacity of $\mathrm{Pb}$ was shown as A. alpina $>A$. margaritacea $>C$. inflatus $>J$. effusus $>A$. orbiculata; the absorption capacity of $\mathrm{Cd}$ was shown as $A$. alpina $>C$. inflatus $>$ A. orbiculata $>J$. effusus $>A$. margaritacea; the absorption capacity of $\mathrm{Cu}$ was shown as $A$. margaritacea $>$ A. alpina $>C$. inflatus $>J$. effusus $>A$. orbiculata; the absorption capacity of $\mathrm{Zn}$ was shown as $A$. alpina $>$ A. orbiculata $>J$. effusus $>$ A. margaritacea $>C$. inflatus. In the same ecological environment, different plants have different capacities to absorb heavy metals. The content of heavy metals in plants was related to the content of heavy metals in the soil where the plants grow, and the ability of plants to transport and absorb heavy metals [6]. A. alpina had a strong ability to accumulate $\mathrm{Cd}$, its BCF and TF were 1.91 and 1.32, and had good transport capacity for $\mathrm{Pb}, \mathrm{Cu}$ and $\mathrm{Zn}$; the TF of $A$. margaritacea, $C$. inflatus and $A$. orbiculata to $\mathrm{Cu}$ and $\mathrm{Zn}>1$, it can be used as $\mathrm{Cu}$ and $\mathrm{Zn}$ tolerant plants; the TF of $J$. effusus to $\mathrm{Cd}$ and $\mathrm{Zn}>1$, it can be used as a tolerant plant for $\mathrm{Cd}$ and $\mathrm{Zn}$. Therefore, studying the plants that grow naturally in mining areas and screening out plant varieties with heavy metal accumulation and tolerance are of great significance for soil restoration and ecological restoration in mining areas.

\section{Conclusion}

The most serious soil heavy metal pollution in Huize lead-zinc mining area was $\mathrm{Cd}$, followed by $\mathrm{Pb}, \mathrm{Zn}$ and $\mathrm{Cu}$. Among the five plants, $A$. alpina had a strong ability to accumulate $\mathrm{Cd}$ and a good transport ability to $\mathrm{Pb}, \mathrm{Cu}$ and Zn. A. margaritacea, C. inflatus and A. orbiculata had good transport ability to $\mathrm{Cu}$ and $\mathrm{Zn}$. J. effusus had good transport ability to $\mathrm{Cd}$ and $\mathrm{Zn}$.

\section{Acknowledgments}

This work was supported by the National Natural Science Foundation of China (41761073, 41967049, 41867055), and Yunnan Provincial Department of Education Science Research Fund Project (2020Y168).

\section{References}

1. Liu X, Zhang Y, Wang N, Mao J. (2015) Pb-Zn metal resources situation and suggestion for $\mathrm{Pb}-\mathrm{Zn}$ metals industry development in China. China Mining Magazine, S1: 6-9.

2. Zhang X P, Hu H X. (2011) Influence of Mineral Resource Exploitation on Ecological Environment and Prevention Countermeasures. Journal of Mining and Strata Control Engineering, 16: 1-5.

3. Zou X L, Zu Y Q, Li Y, Zhan F D. (2014) Pollution and Health Risk Assessment of Cadmium and Lead in Cultivated Soils and Crops Surrounding a Lead-Zinc Mine in Yunnan Province. Journal of Agro-Environment Science, 33: 2143-2148.

4. Ning X Z, Li S. (2017) Basic characteristics and prospecting potential of Yunnan lead zinc deposit. World Nonferrous Metals, 2017: 174-176.

5. Li J W, Zhan F D, He Y M, Guo X H, Li M R, Zu Y Q, Li Y. (2014) Physicochemical and biological properties of soils from Huize lead-zinc mining Physicochemical and biological properties of soils from Huize lead-zinc mining area of Yunnan. Chinese Journal of Applied and Environmental Biology, 20: 906-912.

6. Zhao Y M, Chen S Y, Li Z X, Han H, Hou X L, Cai L P. (2019) Absorption and enrichment effects of herbaceous species on soil heavy metals in the Youxi lead-zinc mining area. Journal of Forest and Environment, 39: 232-240.

7. Miu F J, Su H, Chen L, Wang J H, Xiong Z. (2011) Study on lead-zinc tailings soil and five plants occurring naturally in lead-zinc mining tailings in Lanping. Chinese Journal of Environmental Engineering, 5: 189-194.

8. Zhu G X, Xiao H Y, Guo Q J, Zhang Z Y, Yang X, Kong J. (2017) Subcellular distribution and chemical forms of heavy metals in three types of compositae plants from lead-zinc tailings area. Environmental Science, 38: 3054-3060.

9. Wan X M, Lei M, Yang J X. (2017) Two potential multi-metal hyperaccumulators found in four mining sites in Hunan Province, China. Catena, 148: 67-73.

10. Li S L, Yang B, Chen Y, Lou J, Zhang H X, Qiu Z, Kong L W, Wang R, Ni W Z. (2016) Soil heavy metal pollution and screening of heavy metal super-enriched plants in lead-zinc mining areas of Zhejiang Province. Environmental Pollution \& Control, 38: 48-54. 